\title{
An experimental test of the mechanism by which suspension feeding bivalves elevate seagrass productivity
}

\author{
Bradley J. Peterson ${ }^{1, *}$, Kenneth L. Heck Jr ${ }^{2}$ \\ ${ }^{1}$ Department of Marine Sciences, University of South Alabama, Mobile, Alabama 36688, USA \\ ${ }^{2}$ Dauphin Island Sea Lab, PO Box 369-370 Dauphin Island, Alabama 36528, USA
}

\begin{abstract}
A field experiment utilizing mussel mimics and sediment nutrient enrichment was conducted to examine the effect of the mussel Modilous americanus on meadows of the seagrass Thalassia testudinum. The experimental design tested the separate factors of increased habitat structure and increased nutrient enrichment resulting from the presence of the mussels. Nutrient enrichment had a significantly positive effect on sediment porewater nutrient concentrations and a significantly negative effect on leaf tissue C:N, C:P and N:P ratios. Increased habitat structure had a significantly positive effect on epiphytic grazer densities and a significantly negative effect on epiphytic biomass. In addition, calculated \% light reduction by epiphytes was significantly reduced by structure and significantly increased by nutrient enrichment. This study showed that the direct effect of nutrient enrichment by mussel biodeposition produced the greatest positive response in productivity of $T$. testudinum in the seagrass meadows of St. Joseph Bay, Florida. In other systems experiencing eutrophication, however, it is possible that increased habitat complexity may have the greater effect on seagrass productivity.
\end{abstract}

KEY WORDS: Bentho-pelagic couple · Habitat complexity · Plant-animal interactions · Seagrass · Thalassia testudinum $\cdot$ Suspension feeding bivalves $\cdot$ Modiolus americanus

Resale or republication not permitted without written consent of the publisher

\section{INTRODUCTION}

Nutrient and light availability are considered as 2 of the primary physical factors limiting seagrass distribution (see Dennison 1987, Short 1987 for reviews). Seagrasses are faced with a seeming paradox in their environmental requirements: as autotrophs, they need light to survive, but they are rooted under water, a medium that attenuates light much more strongly than air. In addition to light, they require mineral nutrients to photosynthesize and build tissue. Increases in nutrients in the overlying water column increases light attenuation as a result of plankton or epibiont growth,

\footnotetext{
*Present address: Department of Biological Sciences and the Southeast Research Center, Florida International University, University Park, Miami, Florida 33199, USA.

E-mail: petersob@fiu.edu
}

often leading to the disappearance of seagrass (Orth \& Moore 1983, Giesen et al. 1990, Larkum \& West 1990, Duarte 1995, Short \& Neckles 1999). Several recent studies have examined the effect of suspension feeding bivalves on changing nutrient and light availability to seagrasses.

A few studies have suggested that suspension feeding bivalves increase seagrass nutrient availability without the negative effect of increasing plankton density and reducing light availability. Reusch et al. (1994) demonstrated that the blue mussel Mytilus edulis doubled sediment porewater concentrations of ammonium and phosphate, and suggested that the mussels fertilize the seagrass Zostera marina by the deposition of feces and pseudofeces. Similarly, Reusch \& Williams (1998) demonstrated that the introduced mussel Musculista senhousia fertilized beds of $Z$. marina at moderate bivalve densities. Mechanistically, it seems likely that as 
filter feeding bivalves transfer planktonic production from the water column to the benthos via feces and pseudofeces, they elevate seagrass productivity by increasing nutrient availability. However, the presence of filter feeding bivalves does more than add feces and psuedofeces to the benthos. A recent study investigating the positive interactions between suspension feeding bivalves and seagrass demonstrated that the presence of the mussel Modiolus americanus significantly increased the sediment nutrient pool available to seagrasses, as well as substantially reducing epiphytic biomass on the seagrass leaves (Peterson \& Heck 2001). There are 3 alternative hypotheses as to why seagrasses associated with suspension feeding bivalves may have reduced epiphytic loads: (1) mussels may consume the epiphyte propogules in the water column before they attach to the plant, (2) the elevated productivity of the seagrasses increases blade production rates so that the leaves have less time to accumulate epiphytes, or (3) the presence of suspension feeding bivalves increases the structural complexity of the habitat, reducing predation pressures on epiphytic grazer species such as small gastropods and amphipods. This increased habitat complexity may result in elevated numbers of epiphytic grazers and consequently increased levels of epiphytic grazing. Regardless, the combination of increased sediment nutrient levels and reduced epiphytic loads significantly elevated the productivity of the seagrass Thalassia testudinum associated with Modiolus americanus (Peterson \& Heck 2001). However, several questions remain about which mechanism (increased sediment nutrient levels or reduced epiphytic loads) is responsible for the increased seagrass productivity.

Using density manipulations of mussel mimics and nutrient enrichment of the sediments, the following questions were addressed by this study: (1) how do increasing habitat complexity and nutrient enrichment affect Thalassia testudinum short-shoot (SS) density, above-ground biomass, leaf morphometrics, leaf epiphytic loads and productivity and (2) which effect (nutrient enrichment or reduced epiphyte load) has the greater impact on seagrass productivity?

\section{METHODS}

The effects of nutrient enrichment and increased habitat structure on Thalassia testudinum were observed in St. Joseph Bay, Florida, in the northeastern

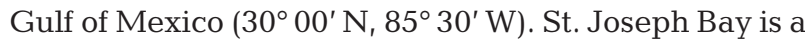
protected shallow coastal embayment where the mean depth is $3 \mathrm{~m}$ and salinities usually range from 30 to $36 \%$ (Stewart \& Gorsline 1962, Folger 1972). Temperatures vary seasonally from approximately 8 to $30^{\circ} \mathrm{C}$ (this study), and the mean tidal range is $0.5 \mathrm{~m}$ (Rudloe 1985).
The bay is oligotrophic with water column nitrogen and phosphorus values seldom exceeding 3 and $0.2 \mu \mathrm{M}$, respectively, and phytoplankton abundance is usually be-

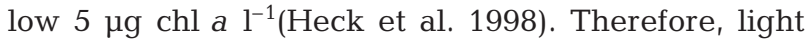
availability for seagrasses is high, with approximately $40 \%$ of measured light at the water surface reaching the seagrass canopy (Heck et al. 1998)

St. Joseph Bay supports an extensive seagrass habitat dominated by large monospecific Thalassia testudinum beds interspersed with smaller patches of Halodule wrightii, unvegetated sand flats and small amounts of Syringodium filiforme (Iverson \& Bittaker 1986). Only the shallowest portions of the seagrass habitat are exposed during low tides, and wave energy is minimal. Associated with these T. testudinum beds is the semi-infaunal tulip mussel, Modiolus americanus, which is found in densities as high as 2000 individuals $\mathrm{m}^{-2}$ (Valentine \& Heck 1993).

Determining potential mechanisms of Thalassiamussel interactions. This experiment was designed to examine the effect of the structure of mussel beds and the nutrient loading caused by mussels on Thalassia testudinum. A $3 \times 3$ factorial incomplete randomized design was used for this experiment, which consisted of 2 factors; structure and nutrient enrichment. Structure had 3 levels: 0, 500 and 1500 mussels $\mathrm{m}^{-2}$ levels. The structure treatment consisted of mussel mimics within the same shell length range ( 45 to $50 \mathrm{~mm}$ ). Mimics were constructed by filling dead mussel valves with clean sand and using Ross cyanoacrylate cement (DURO ${ }^{\mathrm{TM}}$ non-toxic) to seal mussel shells together. In a heavily vegetated portion of a turtlegrass bed, these mimics were added randomly to 6 replicate $0.5 \mathrm{~m}^{2}$ plots $(71 \times 71 \mathrm{~cm})$ within 2 spatially separated treatment arrays (approximately $1.6 \mathrm{~km}$ ). Mimics were sufficiently negatively buoyant to remain in place within the sediment for the duration of the experiment. The mussel densities used in this experiment approximate the range of abundances most often observed in the bay (Valentine \& Heck 1993).

Nutrient enrichment had 3 levels (nutrient loading achieved by 0, 500 and 1500 mussels $\mathrm{m}^{-2}$ ). The nutrient addition treatment was accomplished by adding levels of nutrient approximating the biodeposition rates of Modiolus americanus. Previous literature values of mussel biodeposition rates were used to estimate the amount of nitrogen deposited by $M$. americanus. The average deposition of $\mathrm{N} \mathrm{g}^{-1}$ dry wt of mussel tissue from previous investigations is $1.537 \times 10^{-3} \mathrm{~g} \mathrm{~N} \mathrm{~d}^{-1} \mathrm{~g}^{-1}$ tissue (Jordan \& Valiela 1982, Kautsky \& Evans 1987, Jaramillo et al. 1992). The concentrations of nutrients added to the sediments reflected those estimated for the 2 mussel densities used in the structure treatment $(0.2348 \mathrm{~g} \mathrm{~N}$ $\mathrm{d}^{-1}$ for 500 individuals $\mathrm{m}^{-2} ; 0.7044 \mathrm{~g} \mathrm{~N} \mathrm{~d}^{-1}$ for 1500 individuals $\mathrm{m}^{-2}$ ). In the nutrient enrichment treatments, 
sediment nutrients were increased with slow release Osmocote $^{\mathrm{TM}}$ (cf. Williams 1980, McGlathery 1992) placed on the sediment surface of six $0.5 \mathrm{~m}^{2}$ plots $(\mathrm{n}=3$ for nutrient enrichment produced by 500 and 1500 individuals $\mathrm{m}^{-2}$ ) within each array. Nitrogen and phosphorus were delivered to the sediments primarily in the form of ammonium phosphate and ammonium sulfate in a molar ratio of $\mathrm{N}: \mathrm{P}$ ca 8:1. Nutrient additions were made monthly throughout the experiment except at the height of the growing season (June to August) when nutrient additions occurred at 2 wk intervals.

Finally, there was the structure $\times$ nutrient enrichment interaction treatment. These treatments contained both mussel mimics and the nutrient enrichment estimated for that density of mussels. The $3 \times 3$ factorial design was incomplete because the experiment did not include 2 of the interaction treatments. It did not include the 500 mimics $\mathrm{m}^{-2}$ and nutrient enrichment for 1500 individuals $\mathrm{m}^{-2}$ nor the 1500 mimics $\mathrm{m}^{-2}$ and nutrient enrichment for 500 individuals $\mathrm{m}^{-2}$ treatments. These were excluded because they are biologically unrealistic.

Plot margins of each treatment were marked by anchoring PVC frames to the sediment. Possible translocation of stored nutrients through the seagrass rhizomes out of or into the plots was prevented by severing the rhizomes around the perimeter of each plot. This process was repeated every $3 \mathrm{mo}$. All extant mussels in the plots were removed prior to the initiation of the experiment. This experiment was conducted for $1 \mathrm{yr}$. It was initiated on 18 September 1995, and concluded on 21 September 1996.

Treatment effects on SS density, above-ground biomass, leaf morphometrics, leaf productivity and epiphyte coverage were compared monthly by marking then collecting all SS from randomly selected $0.01 \mathrm{~m}^{2}$ samples from each replicate plot during 1 growing season (6 mo). Leaf production was measured by using the modified leaf marking method of Zieman (1974). In the laboratory, the number of leaves, leaf width, leaf length, daily gross above-ground production, aboveground seagrass biomass, SS density and leaf epibiont biomass (mg $\mathrm{SS}^{-1}$ ) were determined from the harvested SS. Epibiont mass was determined by scraping fouling organisms and algae from each leaf, then drying them to a constant mass $( \pm 0.01 \mathrm{mg})$ in an oven at $60^{\circ} \mathrm{C}$. Following dry weighing, the ash weight was determined by ashing the samples at $500^{\circ} \mathrm{C}$ for $4 \mathrm{~h}$. Ash-free dry weight (AFDW) was calculated as dry weight - ash weight.

Epiphyte grazers were collected every other month by suction sampling the area enclosed by a PVC cylinder (15.24 cm diameter $\times 150 \mathrm{~cm}$ height) held vertically at randomly selected locations on the sediment surface. After the sample was passed through a $0.5 \mathrm{~mm}$ sieve, each individual was identified to the lowest possible taxonomic classification.
Sediment nutrient concentrations were collected every other month for $1 \mathrm{yr}$ using a PVC core $(2 \mathrm{~cm}$ diameter, $15 \mathrm{~cm}$ depth). The sediment samples were dried at $80^{\circ} \mathrm{C}$ for at least $24 \mathrm{~h}$ and homogenized to a fine powder with a mortar and pestle. Total carbon and total nitrogen contents of the sediment samples were determined for each treatment by oxidation in a Carlo Erba Model 1500 CNS analyzer. Phosphorus content was measured using a modification of the method presented in Solorzano \& Sharp (1980) for total particulate phosphorus determination.

To document any potential changes in $\mathrm{N}$ and $\mathrm{P}$ concentrations in leaves due to treatment effects, biomass specific changes in the concentrations of $\mathrm{C}, \mathrm{N}$ and $\mathrm{P}$ in the dried leaves were measured following Fourqurean et al. (1992). Five randomly selected SS were taken from each treatment at the initiation of the experiment (September 1995), at the beginning of the growing season (May 1996) and at the conclusion of the experiment (September 1996). Leaves were gently scraped and washed in flowing tap water to remove epibionts and sediments that had adhered to the leaves. These washed samples were dried to a constant mass and homogenized by milling to a fine powder. The elemental contents of $\mathrm{C}, \mathrm{N}$ and $\mathrm{P}$ of these seagrass leaves were then determined as described above. The data are presented as mol:mol ratios.

The study then consisted of a $3 \times 3$ factorial incomplete randomized design examining the possible mechanisms of Thalassia-mussel interactions: both structure and nutrient enrichment factors had 3 levels $\left(0,500\right.$ and 1500 individuals $\mathrm{m}^{-2}$ or the appropriate nutrient addition equivalent for that density). Each treatment was replicated 3 times in each of 2 spatially separated experimental arrays. Repeated measures ANOVA was utilized to test for significant differences and interactions between structure and nutrient enrichment. Prior to any statistical analysis, ratio data was arcsine transformed. When either factor had a significant effect on the response variable and no interaction occurred, multiple comparison tests (Tukey's Studentized range) were used to test for significant differences between levels within the treatment. Results of the repeated measures ANOVA were considered to be significant if $\mathrm{p}<0.05$.

\section{RESULTS}

\section{Sediment nutrient concentration}

Nutrient enrichment had a significant effect on sediment $C: N, C: P$ and $N: P$ ratios over the course of the experiment (Fig. 1, Table 1). In addition, time had a significant effect on sediment nutrient ratios. As the 
A

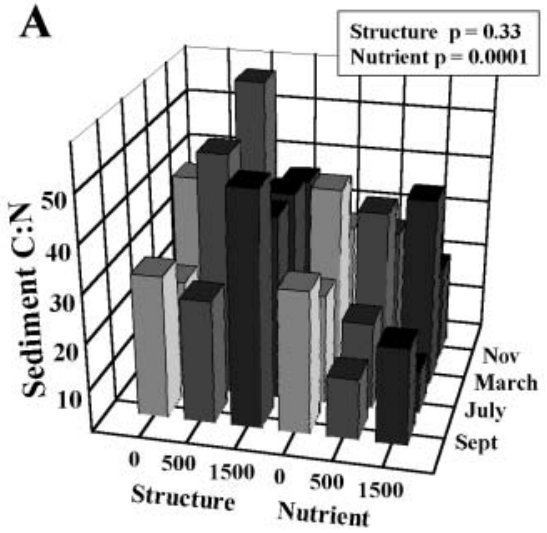

B

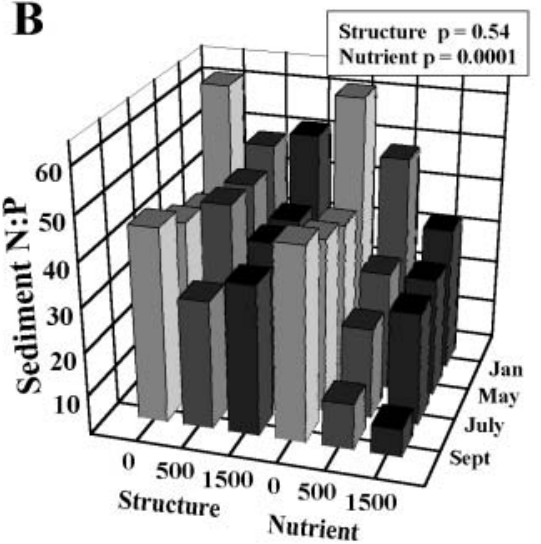

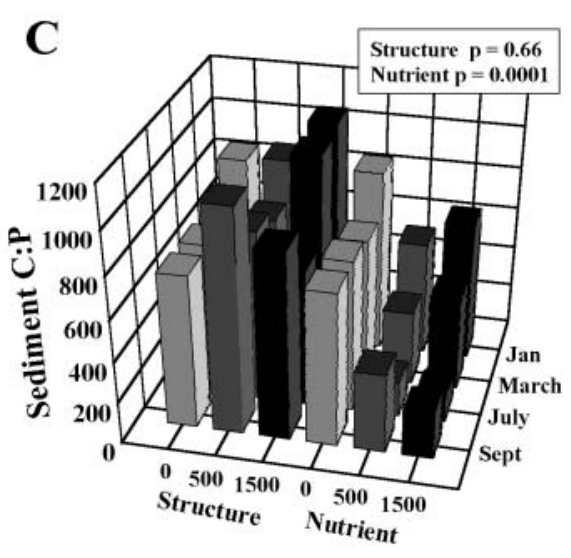

Fig. 1. 3-dimensional plots of the effects of different levels of structure and nutrient on (A) sediment C:N, (B) sediment N:P and (C) sediment C:P ratios by month. Note that the bars are means for each treatment and the 0 structure level and 0 nutrient level are the same data from the 0 structure 0 nutrient plots. The bars become darker with increasing structure or nutrient enrichment

experiment proceeded, sediment nutrient ratios (C:N, C:P and N:P) decreased in the nutrient enrichment treatments. Multiple comparison tests were not conducted because there was a significant time $\times$ nutrient interaction. Conversely, structure (mussel mimics) had no effect on sediment nutrient ratios. However, there was a non-siginificant increasing trend in sediment $\mathrm{C}: \mathrm{P}$ ratios with increasing levels of structure. Thus, structure may have enhanced the accumulation of organic material, but this did not significantly increase the nutrient levels of the sediments. Therefore, this experiment revealed that while structure did not affect sediment nutrient ratios, nutrient enrichment on the sediment surface did, and that the decreasing $C: N$ and $C: P$ ratios indicates that the nutrient addition treatments significantly increased the total nitrogen and total phosphorus pools of the sediments. N:P ratios were significantly reduced by nutrient enrichment $(p<0.001)$, revealing that within the sediments the total phosphorus pool was increasing at a rate greater than that of the total nitrogen pool.

\section{Thalassia testudinum biomass and morphology}

SS densities ranged from 400 to $1600 \mathrm{SS}$ $\mathrm{m}^{-2}$ in the structure treatments and from
Table 1. Repeated measures ANOVA from the $3 \times 3$ factorial experiment for sediment nutrient concentrations

\begin{tabular}{|c|c|c|c|c|c|}
\hline Source & $\mathrm{df}$ & Type III SS & MS & $F$ & $\mathrm{p}>F$ \\
\hline \multicolumn{6}{|l|}{ Sediment C:N ratio } \\
\hline Structure & 2 & 0.0054 & 0.0027 & 1.15 & 0.3359 \\
\hline Nutrient & 2 & 0.0513 & 0.0257 & 11.02 & 0.0005 \\
\hline Structure $\times$ Nutrient & 2 & 0.0003 & 0.0002 & 0.07 & 0.9297 \\
\hline Error (Treatment) & 35 & 0.0489 & 0.0023 & & \\
\hline Time & 3 & 0.2094 & 0.0698 & 5.84 & 0.0014 \\
\hline Time $\times$ Structure & 6 & 0.0572 & 0.0100 & 0.80 & 0.5752 \\
\hline Time $\times$ Nutrient & 6 & 0.2119 & 0.0353 & 2.96 & 0.0132 \\
\hline Time $\times$ Structure $\times$ Nutrient & 6 & 0.1380 & 0.0230 & 1.92 & 0.0905 \\
\hline Error (Time) & 105 & 0.7530 & 0.0120 & & \\
\hline Total & 167 & & & & \\
\hline \multicolumn{6}{|l|}{ Sediment C:P ratio } \\
\hline Structure & 2 & 0.0055 & 0.0027 & 0.43 & 0.6558 \\
\hline Nutrient & 2 & 1.0138 & 0.5069 & 79.25 & 0.0001 \\
\hline Structure $\times$ Nutrient & 2 & 0.0098 & 0.0049 & 0.77 & 0.4770 \\
\hline Error (Treatment) & 35 & 0.1343 & 0.0063 & & \\
\hline Time & 3 & 0.2302 & 0.0767 & 7.27 & 0.0003 \\
\hline Time $\times$ Structure & 6 & 0.1160 & 0.0193 & 1.83 & 0.1071 \\
\hline Time $\times$ Nutrient & 6 & 0.1308 & 0.0218 & 2.07 & 0.0700 \\
\hline Time $\times$ Structure $\times$ Nutrient & 6 & 0.1499 & 0.0249 & 2.37 & 0.0399 \\
\hline Error (Time) & 105 & 0.6652 & 0.0106 & & \\
\hline Total & 167 & & & & \\
\hline \multicolumn{6}{|l|}{ Sediment N:P ratio } \\
\hline Structure & 2 & 0.0241 & 0.0120 & 0.64 & 0.5370 \\
\hline Nutrient & 2 & 1.3198 & 0.6598 & 35.09 & 0.0001 \\
\hline Structure $\times$ Nutrient & 2 & 0.0797 & 0.0398 & 2.12 & 0.1450 \\
\hline Error (Treatment) & 35 & 0.3949 & 0.0188 & & \\
\hline Time & 3 & 1.8624 & 0.6208 & 21.83 & 0.0001 \\
\hline Time $\times$ Structure & 6 & 0.1403 & 0.0234 & 0.82 & 0.5570 \\
\hline Time $\times$ Nutrient & 6 & 0.4385 & 0.0731 & 2.57 & 0.0270 \\
\hline Time $\times$ Structure $\times$ Nutrient & 6 & 0.0928 & 0.0155 & 0.54 & 0.7730 \\
\hline Error (Time) & 105 & 1.7916 & 0.0284 & & \\
\hline Total & 167 & & & & \\
\hline
\end{tabular}



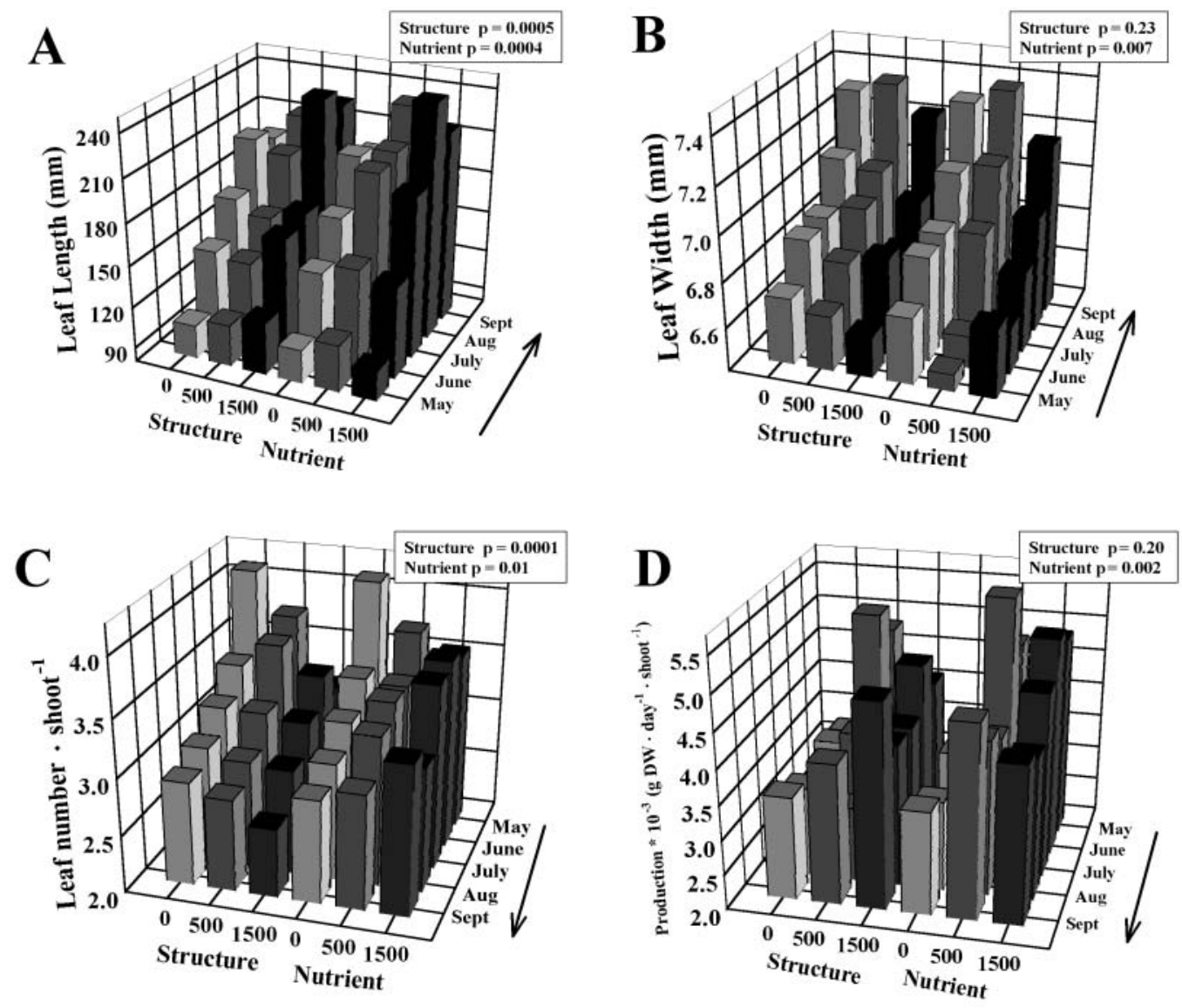

Fig. 2. 3-dimensional plots of the effects of different levels of structure and nutrient on Thalassia testudinum leaf morphology. (A) Leaf length in $\mathrm{mm}$, (B) leaf width in $\mathrm{mm}$, (C) leaf number shoot ${ }^{-1}$ and (D) Thalassia testudinum productivity (g dry wt $\mathrm{d}^{-1}$ shoot $^{-1}$ ) by month. Note that the bars are means for each treatment and the 0 structure level and 0 nutrient level are the same data from the 0 structure 0 nutrient plots. The bars become darker with increasing structure or nutrient enrichment

500 to $1700 \mathrm{~m}^{-2}$ in the nutrient enrichment treatments over the duration of the experiment. The mean SS densities $( \pm \mathrm{SD})$ by treatments over the course of the entire growing season (April to Sept) were $1016 \pm 264$ for the 500 mimics $\mathrm{m}^{-2}, 983 \pm 227$ for the 1500 mimics $\mathrm{m}^{-2}, 1067 \pm 227$ for the nutrient enrichment of 500 individuals $\mathrm{m}^{-2}$ and $997 \pm 235$ for the nutrient enrichment of 1500 individuals $\mathrm{m}^{-2}$. Neither structure nor nutrient enrichment had a significant effect on SS densities ( $p=0.66$ and $p=0.61$, respectively; Table 2). Above-ground biomass ranged from 54 to $266 \mathrm{~g}$ dry wt $\mathrm{m}^{-2}$ in the structure treatments, and from 74 to $294 \mathrm{~g}$ dry wt $\mathrm{m}^{-2}$ in the nutrient enrichment treatments over the same time period. Again, neither structure nor nutrient enrichment had a significant effect on above-ground biomass ( $p=0.56$ and $\mathrm{p}=0.15$, respectively). However, structure and nutrient enrichment both had a significant effect on leaf length (Fig. 2, Table 2). Although multiple comparisons were not tested due to a significant time $\times$ structure $\times$ nutrient interaction, the longest leaves were found consistently in the highest structure and highest nutrient treatments. In addition to leaf length, nutrient enrichment had a significantly negative effect on leaf width ( $p=0.007)$, while structure had no effect ( $p=0.23$, Fig. 2). Because there was a significant time $\times$ nutrient interaction, no within-treatment effects are discussed. Finally, structure and nutrient enrichment both had a significant affect on leaf number (Fig. 2). Structure had a negative effect on leaf number $(p=0.0001)$. Conversely, nutrient enrichment had a positive effect on leaf number $(p=0.01)$. Leaf number was also negatively affected by time $(p=0.0001)$. No within-treatment effects are discussed because of a significant time $\times$ structure $\times$ nutrient interaction. Overall, nutrient enrichment treatments resulted in seagrass SS with a greater number of narrower, longer leaves, while structure treatments resulted in SS with a fewer number of wider, longer leaves. 
A

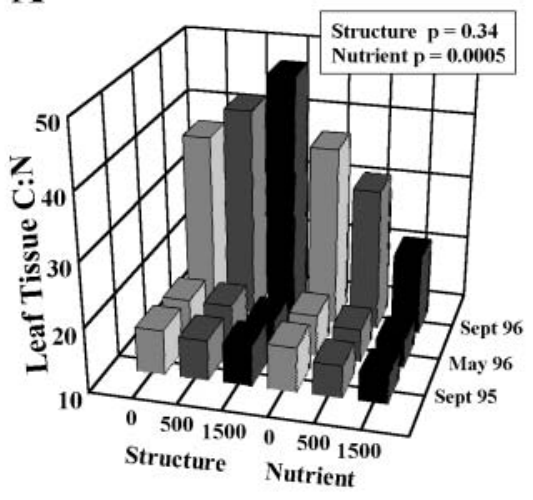

B

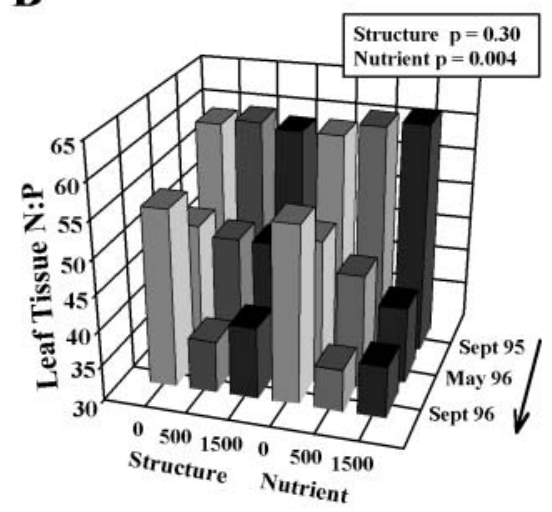

C

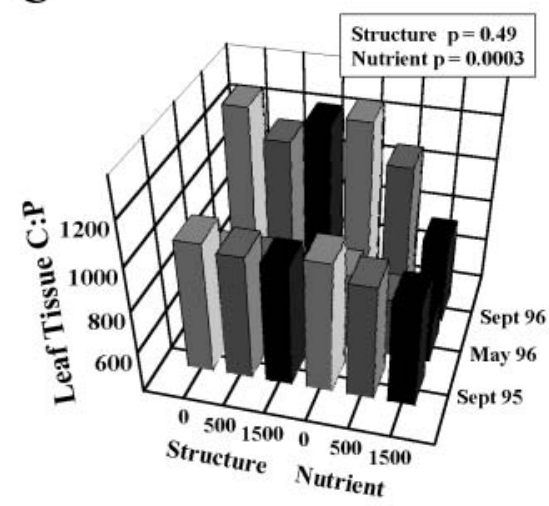

Fig. 3. 3-dimensional plots of the effects of different levels of structure and nutrient on Thalassia testudinum leaf tissue (A) C:N, (B) N:P and (C) C:P ratios by month. Note the change in direction of the time axis indicated by the arrow in (B). Note that the bars are means for each treatment and the 0 structure level and 0 nutrient level are the same data from the 0 structure 0 nutrient plots. The bars become darker with increasing structure or nutrient enrichment

\section{Leaf tissue $C: N, C: P$ and $\mathrm{N}: \mathrm{P}$ concentrations}

Structure had no significant impact on leaf tissue $\mathrm{C}: \mathrm{N}$ or $\mathrm{C}: \mathrm{P}$ ratios $(\mathrm{p}=0.34$ and $\mathrm{p}=0.49$, respectively) (Fig. 3, Table 2). In contrast, nutrient enrichment had a significant effect on both $\mathrm{C}: \mathrm{N}$ and $\mathrm{C}: \mathrm{P}$ leaf tissue ratios. $\mathrm{C}: \mathrm{N}$ ratios ranged from 13 to 31 in the structure treatments with a mean of $18 \pm 6$ in treatments with nutrient enrichment for 500 mussels $\mathrm{m}^{-2}$ and $15 \pm 3$ in treatments with nutrient enrichment for 1500 mussels $\mathrm{m}^{-2}$. There was also a significant effect of time on both ratios. Leaf tissue N:P ratios were significantly reduced by nutrient enrichment $(p=0.004)$. Therefore, while structure had no effect on leaf tissue nutrient ratios, nutrient enrichment treatments significantly increased the amount of $\mathrm{N}$ and $\mathrm{P}$ in the leaves. The N:P ratio changes suggest that the leaves are accumulating more $\mathrm{P}$ and may eventually become $\mathrm{N}$-limited.

\section{Primary production}

Structure had no significant effect on Thalassia testudinum production $(\mathrm{p}=0.20)$ (Fig. 2, Table 2). However, net aboveground primary production (NAPP) responded positively with increasing nutri-
Table 2. Thalassia testudinum. Repeated measures ANOVA from the $3 \times 3$ factorial experiment for response variables

\begin{tabular}{|c|c|c|c|c|c|}
\hline Source & df & Type III SS & MS & $F$ & $\mathrm{p}>F$ \\
\hline \multicolumn{6}{|l|}{ Shoot density } \\
\hline Structure & 2 & 57355.55 & 28677.77 & 0.43 & 0.6548 \\
\hline Nutrient & 2 & 68022.22 & 34011.11 & 0.51 & 0.6059 \\
\hline Structure $\times$ Nutrient & 2 & 56533.33 & 28266.67 & 0.42 & 0.6588 \\
\hline Error (Treatment) & 35 & 2342333.33 & 66923.81 & & \\
\hline Time & 4 & 772685.19 & 193171.30 & 6.12 & 0.0001 \\
\hline Time $\times$ Structure & 8 & 175422.22 & 21927.78 & 0.70 & 0.6953 \\
\hline Time $\times$ Nutrient & 8 & 445866.67 & 55733.33 & 1.77 & 0.0885 \\
\hline Time $\times$ Structure $\times$ Nutrient & ht 8 & 677911.11 & 84738.89 & 2.69 & 0.0089 \\
\hline Error (Time) & 140 & 4416000.00 & & & \\
\hline Total & 209 & & & & \\
\hline \multicolumn{6}{|l|}{ Above-ground biomass } \\
\hline Structure & 2 & 1868.70 & 934.35 & 0.59 & 0.5644 \\
\hline Nutrient & 2 & 6509.73 & 3254.87 & 2.05 & 0.1540 \\
\hline Structure $\times$ Nutrient & 2 & 11303.81 & 5651.91 & 3.56 & 0.0468 \\
\hline Error (Treatment) & 21 & 33373.06 & 1589.19 & & \\
\hline Time & 4 & 171716.27 & 42929.07 & 43.68 & 0.0001 \\
\hline Time $\times$ Structure & 8 & 14482.39 & 1810.30 & 1.84 & 0.0805 \\
\hline Time $\times$ Nutrient & 8 & 7652.84 & 956.61 & 0.97 & 0.4625 \\
\hline Time $\times$ Structure $\times$ Nutrient & ht 8 & 29885.86 & 3735.73 & 3.80 & 0.0008 \\
\hline Error (Time) & 84 & 82560.73 & & & \\
\hline Total & 139 & & & & \\
\hline \multicolumn{6}{|l|}{ Leaf length } \\
\hline Structure & 2 & 156077.73 & 78038.86 & 7.66 & 0.0005 \\
\hline Nutrient & 2 & 160025.43 & 80012.71 & 7.85 & 0.0004 \\
\hline Structure $\times$ Nutrient & 2 & 19066.46 & 9533.23 & 0.94 & 0.3926 \\
\hline Error (Treatment) & 1027 & 10461594.10 & 59.48 & & \\
\hline Time & 4 & 9346087.26 & 2336521.81 & 260.32 & 0.0001 \\
\hline Time $\times$ Structure & 8 & 98421.60 & 12302.69 & 1.37 & 0.2040 \\
\hline Time $\times$ Nutrient & 8 & 344189.79 & 43023.72 & 4.79 & 0.0001 \\
\hline Time $\times$ Structure $\times$ Nutrient & ht 8 & 170725.55 & 21340.69 & 2.38 & 0.0149 \\
\hline Error (Time) & 4108 & 36871900.98 & & & \\
\hline Total & 5169 & & & & \\
\hline
\end{tabular}


Table 2 (continued)

\begin{tabular}{|c|c|c|c|c|c|}
\hline Source & df & Type III SS & MS & $F$ & $\mathrm{p}>F$ \\
\hline \multicolumn{6}{|l|}{ Leaf number } \\
\hline Structure & 2 & 17.3417 & 8.6708 & 11.46 & 0.0001 \\
\hline Nutrient & 2 & 7.0518 & 3.5259 & 4.66 & 0.0102 \\
\hline Structure $\times$ Nutrient & 2 & 0.1881 & 0.0940 & 0.12 & 0.8832 \\
\hline Error (Treatment) & 297 & 224.6951 & 0.7566 & & \\
\hline Time & 4 & 139.5855 & 34.8964 & 43.98 & 0.0001 \\
\hline Time $\times$ Structure & 8 & 8.3565 & 1.0446 & 1.32 & 0.2309 \\
\hline Time $\times$ Nutrient & 8 & 11.3679 & 1.4210 & 1.79 & 0.0790 \\
\hline Time $\times$ Structure $\times$ Nutrient & 8 & 18.3960 & 2.2995 & 2.90 & 0.0033 \\
\hline Error (Time) & 1188 & 942.5995 & & & \\
\hline Total & 1519 & & & & \\
\hline \multicolumn{6}{|l|}{ Leaf tissue C:N ratio } \\
\hline Structure & 2 & 0.0054 & 0.0027 & 1.15 & 0.3359 \\
\hline Nutrient & 2 & 0.0513 & 0.0257 & 11.02 & 0.0005 \\
\hline Structure $\times$ Nutrient & 2 & 0.0003 & 0.0002 & 0.07 & 0.9297 \\
\hline Error (Treatment) & 35 & 0.0490 & 0.0023 & & \\
\hline Time & 2 & 0.4004 & 0.2002 & 106.97 & 0.0001 \\
\hline Time $\times$ Structure & 4 & 0.0112 & 0.0028 & 1.49 & 0.2217 \\
\hline Time $\times$ Nutrient & 4 & 0.0601 & 0.0150 & 8.02 & 0.0001 \\
\hline Time $\times$ Structure $\times$ Nutrient & 4 & 0.0092 & 0.0023 & 1.23 & 0.3131 \\
\hline Error (Time) & 70 & 0.0786 & & & \\
\hline Total & 125 & & & & \\
\hline \multicolumn{6}{|l|}{ Leaf tissue C:P ratio } \\
\hline Structure & 2 & 0.0009 & 0.0005 & 0.74 & 0.4894 \\
\hline Nutrient & 2 & 0.0149 & 0.0075 & 11.94 & 0.0003 \\
\hline Structure $\times$ Nutrient & 2 & 0.0038 & 0.0019 & 3.02 & 0.0706 \\
\hline Error (Treatment) & 35 & 0.0132 & 0.0006 & & \\
\hline Time & 2 & 0.1158 & 0.0579 & 208.59 & 0.0001 \\
\hline Time $\times$ Structure & 4 & 0.0016 & 0.0004 & 1.46 & 0.2314 \\
\hline Time $\times$ Nutrient & 4 & 0.0089 & 0.0022 & 8.10 & 0.0001 \\
\hline Time $\times$ Structure $\times$ Nutrient & 4 & 0.0013 & 0.0033 & 1.20 & 0.3263 \\
\hline Error (Time) & 70 & 0.0117 & & & \\
\hline Total & 125 & & & & \\
\hline \multicolumn{6}{|l|}{ Leaf tissue N:P ratio } \\
\hline Structure & 2 & 0.0046 & 0.0023 & 1.29 & 0.2954 \\
\hline Nutrient & 2 & 0.0253 & 0.0127 & 7.13 & 0.0043 \\
\hline Structure $\times$ Nutrient & 2 & 0.0035 & 0.0018 & 0.99 & 0.3867 \\
\hline Error (Treatment) & 35 & 0.0373 & 0.0018 & & \\
\hline Time & 2 & 0.1858 & 0.0929 & 82.02 & 0.0001 \\
\hline Time $\times$ Structure & 4 & 0.0091 & 0.0023 & 2.00 & 0.1384 \\
\hline Time $\times$ Nutrient & 4 & 0.0269 & 0.0067 & 5.94 & 0.0031 \\
\hline Time $\times$ Structure $\times$ Nutrient & 4 & 0.0068 & 0.0017 & 1.50 & 0.2368 \\
\hline Error (Time) & 70 & 0.0476 & & & \\
\hline Total & 125 & & & & \\
\hline \multicolumn{6}{|l|}{ Thalassia production } \\
\hline Structure & 2 & 3.3081 & 1.6541 & 1.75 & 0.1979 \\
\hline Nutrient & 2 & 15.4012 & 7.7006 & 8.15 & 0.0024 \\
\hline Structure $\times$ Nutrient & 2 & 7.2202 & 3.6101 & 3.82 & 0.0384 \\
\hline Error (Treatment) & 35 & 19.8310 & 0.9443 & & \\
\hline Time & 4 & 23.9325 & 5.9831 & 9.76 & 0.0001 \\
\hline Time $\times$ Structure & 8 & 6.2718 & 0.7839 & 1.28 & 0.2656 \\
\hline Time $\times$ Nutrient & 8 & 5.3410 & 0.6676 & 1.09 & 0.3790 \\
\hline Time $\times$ Structure $\times$ Nutrient & 8 & 8.7099 & 1.0887 & 1.78 & 0.0933 \\
\hline Error (Time) & 140 & 51.5010 & 0.6131 & & \\
\hline Total & 209 & & & & \\
\hline
\end{tabular}

ent enrichment. Unlike structure, nutrient addition produced significantly greater productivity $(\mathrm{p}=0.002)$. While NAPP ranged from 2.57 to $5.05 \mathrm{~g}$ dry wt $\mathrm{m}^{-2} \mathrm{~d}^{-1}$ over the entire growing season for the no structure-no nutrient treatments, it ranged from 2.4 to $6.63 \mathrm{~g}$ dry wt $\mathrm{m}^{-2} \mathrm{~d}^{-1}$ for the structure treatments and from 3.4 to $8.04 \mathrm{~g}$ dry $\mathrm{wt}$ $\mathrm{m}^{-2} \mathrm{~d}^{-1}$ for the nutrient enrichment treatments. Mean NAPP for $500 \mathrm{mim}$ ics $\mathrm{m}^{-2}$ was $4.17 \pm 0.94 \mathrm{~g}$ dry wt $\mathrm{m}^{-2} \mathrm{~d}^{-1}$ and $4.42 \pm 0.96 \mathrm{~g}$ dry wt $\mathrm{m}^{-2} \mathrm{~d}^{-1}$ for 1500 mimics $\mathrm{m}^{-2}$. Similarly, NAPP for the nutrient enrichment treatments was $4.77 \pm 1.23 \mathrm{~g}$ dry wt $\mathrm{m}^{-2} \mathrm{~d}^{-1}$ and $4.75 \pm 0.88 \mathrm{~g}$ dry wt $\mathrm{m}^{-2} \mathrm{~d}^{-1}$ for the 500 and 1500 individuals $\mathrm{m}^{-2}$ nutrient addition treatments, respectively. Although there appeared to be a trend of increasing $T$. testudinum productivity with increasing structure over the course of the experiment, it was not significant. In contrast, nutrient enrichment did significantly elevate $T$. testudinum productivity.

\section{Epiphytic biomass}

Overall, nutrient enrichment had no significant effect on epiphytic biomass ( $p=0.30$ ) (Fig. 4, Table 3). However, in July and August there appeared to be increased epiphytic biomass with increased levels of nutrients. Conversely, structure did have a significant effect on epiphytic biomass ( $p<0.001)$. Epiphytic biomass on the leaves was significantly decreased in structure treatments every month except July. Therefore, although nutrients had no significant effect on epiphyte biomass on the leaves (and may actually stimulate epiphyte growth), structure treatments resulted in significantly lower epiphytic leaf loads. Using an equation from Fong \& Harwell (1994), the \% light reduction attributed to the presence of epiphytic loads on the seagrass leaves was calculated. Repeated measures ANOVA based on the calculated $\%$ light reduction by epiphytes revealed that structure resulted in significantly less light reduction $(p=0.001)$, 

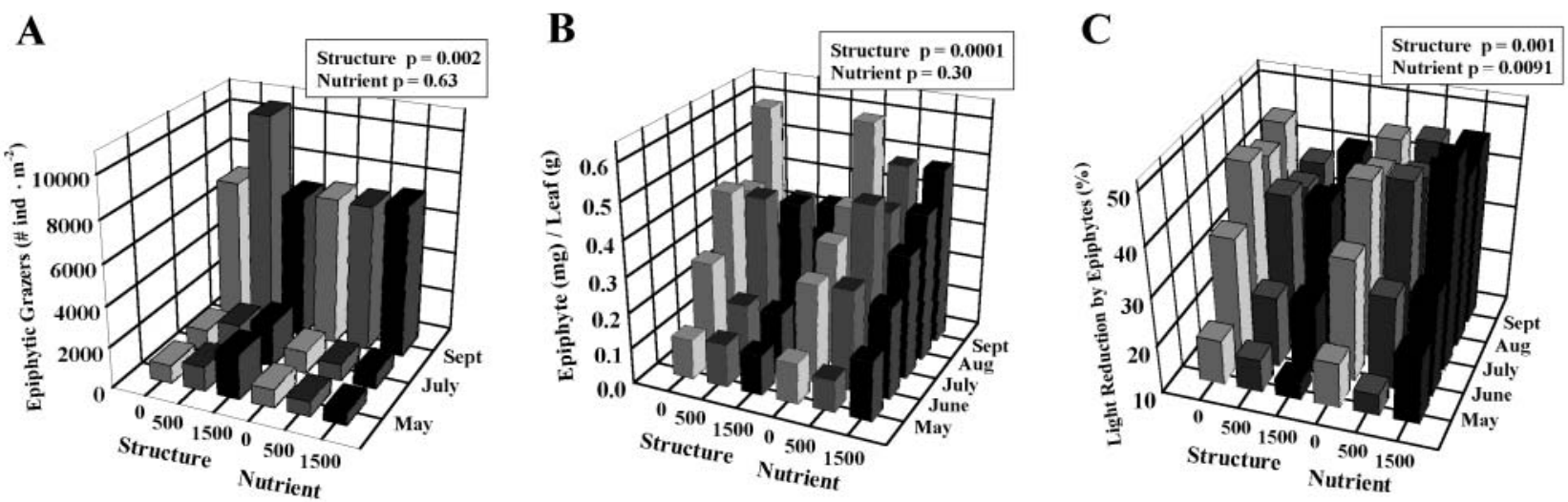

Fig. 4. 3-dimensional plots of the effects of different levels of structure and nutrient on (A) epiphytic grazer densities (individuals $\mathrm{m}^{-2}$ ), (B) epiphyte biomass (mg epiphyte AFDW g ${ }^{-1}$ leaf dry wt) and (C) \% light reduction (calculated by the equation of Fong \& Harwell 1994) by month. Note that the bars are means for each treatment and the 0 structure level and 0 nutrient level are the same data from the 0 structure 0 nutrient plots. The bars become darker with increasing structure or nutrient enrichment

Table 3. Repeated measures ANOVA from the $2 \times 3$ factorial experiment for epiphytic grazer density and epiphyte biomass

\begin{tabular}{|c|c|c|c|c|c|}
\hline Source & $\mathrm{df}$ & Type III SS & MS & $F$ & $\mathrm{p}>F$ \\
\hline \multicolumn{6}{|l|}{ Epiphyte biomass } \\
\hline Structure & 2 & 0.1986 & 0.0994 & 19.04 & 0.0001 \\
\hline Nutrient & 2 & 0.0135 & 0.0068 & 1.29 & 0.2954 \\
\hline Structure $\times$ Nutrient & 2 & 0.0186 & 0.0093 & 1.78 & 0.1926 \\
\hline Error (Treatment) & 35 & 0.1097 & 0.0052 & & \\
\hline Time & 4 & 1.7631 & 0.4408 & 73.53 & 0.0001 \\
\hline Time $\times$ Structure & 8 & 0.1175 & 0.0147 & 2.45 & 0.0196 \\
\hline Time* Nutrient & 8 & 0.0481 & 0.0060 & 1.00 & 0.4395 \\
\hline Time $\times$ Structure $\times$ Nutrient & 8 & 0.0563 & 0.0070 & 1.17 & 0.3239 \\
\hline Error (Time) & 140 & 0.5035 & 0.0060 & & \\
\hline Total & 209 & & & & \\
\hline \multicolumn{6}{|l|}{ Epiphytic grazer density } \\
\hline Structure & 2 & 55729605 & 27864802 & 8.55 & 0.0019 \\
\hline Nutrient & 2 & 3110320 & 1555160 & 0.48 & 0.6271 \\
\hline Structure ${ }^{*}$ Nutrient & 2 & 6779154 & 3389577 & 1.04 & 0.3710 \\
\hline Error (Treatment) & 35 & 68446165 & 3259341 & & \\
\hline Time & 2 & 7340683633 & 367034181 & 102.91 & 0.0001 \\
\hline Time $\times$ Structure & 4 & 43000876 & 10750219 & 3.01 & 0.0322 \\
\hline Time $\times$ Nutrient & 4 & 10887590 & 2721897 & 0.76 & 0.5469 \\
\hline Time $\times$ Structure $\times$ Nutrient & 4 & 6104370 & 1526092 & 0.43 & 0.7741 \\
\hline Error (Time) & 70 & 149788667 & 3566396 & & \\
\hline Total & 125 & & & & \\
\hline \multicolumn{6}{|l|}{ \% Light reduction by epiphytes } \\
\hline Structure & 2 & 802.4735 & 401.2367 & 22.45 & 0.0001 \\
\hline Nutrient & 2 & 211.6291 & 105.8146 & 5.92 & 0.0091 \\
\hline Structure $\times$ Nutrient & 2 & 54.3082 & 27.1541 & 1.52 & 0.2420 \\
\hline Error (Treatment) & 35 & 375.3704 & 17.8748 & & \\
\hline Time & 2 & 14444.6898 & 3611.1725 & 80.37 & 0.0001 \\
\hline Time $\times$ Structure & 4 & 313.1051 & 1039.1381 & 0.87 & 0.5442 \\
\hline Time $\times$ Nutrient & 4 & 302.6027 & 37.8253 & 0.84 & 0.5687 \\
\hline Time $\times$ Structure $\times$ Nutrient & 4 & 468.1667 & 58.5208 & 1.30 & 0.2535 \\
\hline Error (Time) & 140 & 3774.2356 & 44.9314 & & \\
\hline Total & 209 & & & & \\
\hline
\end{tabular}

while nutrient enrichment resulted in significantly greater light reduction $(\mathrm{p}=0.009)$.

Similarly, nutrient enrichment did not significantly affect epiphytic grazer densities ( $p=0.63)$, while structure did $(\mathrm{p}=0.002)$ (Fig. 4, Table 3). There were significantly greater densities of epiphytic grazers associated with the structure treatments. There was also a significant effect of time on epiphytic grazer densities. Multiple comparison analysis was not conducted due to a significant time $\times$ structure interaction. Overall, structure resulted in significantly lower epiphytic biomass on the leaves and greater epiphytic grazer densities, while nutrient had no significant effect on either epiphytic biomass or grazers.

\section{DISCUSSION}

In shallow coastal waters, suspension feeding bivalves often dominate the benthos in numbers as well as in biomass. In the Gulf of Mexico and the Caribbean Sea these filter feeders are usually associated with seagrass. A previously conducted field experiment examined the positive interactions between the suspension feeding mussel Modiolus americanus and the seagrass Thalassia testudinum (Peterson 
\& Heck 2001). Their mussel density manipulations resulted in the doubling of the total nitrogen and total phosphorus levels of the sediments and, thus, the significant reduction of leaf tissue $\mathrm{C}: \mathrm{N}$ and $\mathrm{C}: \mathrm{P}$ ratios; demonstrating that the mussels increased the sediment nutrient content and that these increased nutrients were biologically available to the plant. T. testudinum responded to the presence of mussels by significantly increasing leaf lengths and productivity. In addition, the presence of mussels resulted in a significant reduction in epiphytic loads on the seagrass leaves. Consequently, when mussels were present in seagrass meadows, they elevated seagrass productivity through either increased nutrient resource pools or reduced epiphytic loads on the leaves.

The purpose of this study was to test which effect of the presence of mussels (increased sediment nutrient levels or decreased epiphytic loads on the leaves) had the greatest impact on seagrass producitivity. By using mussel mimics and nutrient additions to the sediment surface, this experiment allowed the 2 potential mechanisms of increasing seagrass productivity to be uncoupled and tested. Similar to the previously conducted mussel addition manipulations (Peterson \& Heck 2001), the nutrient enrichment treatments increased the amount of total nitrogen and total phosphate in the sediments, altering leaf tissue $\mathrm{C}: \mathrm{N}$ and $\mathrm{C}: \mathrm{P}$ ratios. In this experiment, structure had no effect on sediment nutrient levels or on leaf tissue nutrient content. Prior to this investigation, it might have been argued that the increased habitat complexity resulting from the presence of mussels enhances the accumulation of detrital material. The increasing $\mathrm{C}: \mathrm{N}$ ratios of the sediments associated with the mimics in this study seemingly support this; however, structure produced no significant changes in the sediment nutrient ratios. Therefore, this experiment indicates that the increase in sediment nutrient pools and leaf tissue levels in the previously conducted live mussel density manipulation (Peterson \& Heck 2001) can be attributed solely to the effect of biodeposition.

While SS densities and above-ground biomass were unaffected by either structure or nutrient enrichment, the plant's morphology was significantly altered by both factors. Structure resulted in SS with significantly fewer, longer leaves. In contrast, nutrient enrichment treatments resulted in SS with significantly more, narrower and longer leaves. In the previous live mussel manipulation experiment (Peterson \& Heck 2001), the presence of mussels resulted in significant changes in leaf number and length. Seagrass SS had fewer leaves in mussel treatments early in the growing season. However, by the end of the growing season this trend had reversed and seagrass SS had more leaves in the mussel treatments than did the control treatments with no mussels. From this experiment, we can infer that mussel structure had a greater influence on SS leaf number early in the growing season, while mussel biodeposition had a greater impact in the late growing season. Interestingly, in the factorial experiment both structure and nutrient enrichment resulted in significantly longer leaves.

In this experiment, productivity of Thalassia testudinum was significantly altered by nutrient enrichment, though not by structure. Increased rates of productivity were measured for every month of the growing season for both factors, and these elevated rates of productivity reached levels twice those of the no structure-no nutrient enrichment treatments. However, only nutrient enrichment had a significantly positive effect on T. testudinum productivity. Therefore, this experiment demonstrates that the effect of nutrient enrichment resulting from mussel biodeposition is the primary factor responsible for elevating seagrass productivity in St. Joseph Bay.

In the previous live mussel density manipulation experiment (Peterson \& Heck 2001), the presence of Modiolus americanus significantly reduced epiphytic biomass on the seagrass leaves. In this experiment, structure resulted in significantly reduced epiphytic loads on the leaves. Nutrient enrichment had no significant effect on epiphytic biomass. This experiment allows 2 of the alternative hypotheses, presented in the 'Introduction' for explaining reduced epiphytic loads on the leaves of seagrasses associated with mussels, to be rejected. If the mussels were consuming the epiphyte propogules in the water column before they attached to the plant, then one would not expect to see a decrease in epiphytic loads on leaves in the structure treatments (since the mimics were incapable of consumption). Similarly, if elevated blade production rates were responsible for reducing epiphytic loads by giving the leaves less time to accumulate epiphytes then, since both structure and nutrient enrichment have had similar rates of blade production, they should have similar epiphytic loads, which they did not. The third alternative, that the presence of suspension feeding bivalves increases the structural complexity of the habitat reducing predation pressures on epiphytic grazer species, cannot be rejected.

Quantitative suction sampling of the structure and nutrient enrichment treatments revealed that structure significantly increased the densities of epiphytic grazers, while nutrient enrichment had no effect. Therefore, this experiment seems to suggest that the presence of the mussels elevates epiphytic grazer densities, which are responsible for the reduced epiphyte loads on the leaves of seagrasses associated with mussels. 
Using an equation from Fong \& Harwell (1994), the $\%$ light reduction attributed to the presence of epiphytic loads on the seagrass leaves was calculated. Both structure and nutrient had a significant effect on light reduction by epiphytes. Structure significantly reduced epiphytic shading, while nutrient significantly increased light reduction by epiphytes. The role of epiphytes in attenuation of light has been well demonstrated (for review see Orth \& van Montfrans 1984, Neckles et al. 1993). Although structure had no significant effect on Thalassia testudinum productivity in this experiment, the dramatic decrease in epiphytic biomass and consequent \% light reduction by epiphytes resulting from the structure treatment suggests that the presence of mussels could play a significant role in increasing seagrass productivity where epiphytic loads are greater than those observed in St. Joseph Bay.

The experimental design allowed both the independent and interactive effects of structure and nutrient enrichment to be examined. Comparing the effects of structure and nutrient enrichment with those of the live mussel manipulations revealed the relative importance of each factor on Thalassia testudinum productivity. Nutrient enrichment produced a similar response in sediment nutrient pools as that of the live mussel manipulations, while structure had no effect on sediment nutrient concentration. Similarly, structure resulted in significantly reduced epiphytic loads similar to those of the live mussel manipulations. The results of this experiment indicate that the productivity of the T. testudinum community in St. Joseph Bay is limited primarily by nutrient availability.

The overall significance of this study lies in its attempt to understand the processes that control the productivity and abundance of seagrass. This study tested the different effects of 2 beneficial consequences of Modiolus americanus on seagrasses. First, M. americanus was found to have a major influence on sediment nutrient enrichment. Aggregates of $M$. americanus significantly increased the nutrient pool of nitrogen and phosphate available to Thalassia testudinum. Hence, M. americanus patches may serve as nutrient 'hot spots' within seagrass assemblages. The dramatic increase in phosphate may have an even more significant impact on seagrasses where carbonate sediments dominate. Second, the epiphytic biomass on the leaves of $T$. testudinum was significantly altered by the presence of $M$. americanus. Although the impact of these reduced epiphytic loads resulted in increased production only near the end of the growing season, the extension of elevated productivity may have substantial consequences on the stability of seagrass assemblages. This may be particularly important to areas experiencing increased levels of eutrophication.
Acknowledgements. The authors would like to thank Brenda Peterson, Barbara Flom, Kimbrough Ferrell, Susan Sklenar, Katherine Canter, Trisha Spitzer, Paul Bologna and Jean Cowan for field and laboratory assistance. This paper has been substantially improved via many discussions and helpful comments from John Valentine, Jim Cowan and Mark Bertness. Funding for this project was provided in part by the Mississippi-Alabama Sea Grant, University of South Alabama and the Dauphin Island Sea Lab. We thank the Dauphin Island Sea Lab faculty and staff for their help in all phases of this project. This is contribution no. 332 of the Marine Environmental Science Consortium, contribution no. 158 for the Southeast Environmental Research Center and contribution no. 39 for the Tropical Biology Program at FIO.

\section{LITERATURE CITED}

Dennison WC (1987) Effects of light on seagrass photosynthesis, growth and depth distribution. Aquat Bot 27:15-26

Duarte CM (1995) Submerged aquatic vegetation in relation to different nutrient regimes. Ophelia 41:87-112

Folger DW (1972) Characteristics of estuarine sediments of the United States. US Geol Surv, Prof Paper No. 742, p 1-95

Fong P, Harwell MA (1994) Modeling seagrass communities in tropical and subtropical bays and estuaries: a mathematical model synthesis of current hypotheses. Bull Mar Sci 54:757-781

Fourqurean JW, Zieman JC, Powell GVN (1992) Relationships between porewater nutrients and seagrasses in a subtropical carbonate environment. Mar Biol 114:57-65

Giesen R, Vankatwi MM, Den Hartog C (1990) Temperature, salinity, insolation, and wasting disease of eelgrass (Zostera marina L.) in the Dutch Wadden Sea in the 1930's. Neth J Sea Res 25:395-404

Heck KL Jr, Carlson P, Canter K, Yarbro L (1998) Response of the segrass Thalassia testudinum and Halodule wrightii to relaxation of shading in mesocosm and in St. Joseph's Bay, Florida. Completion report for US Environ Prot Agency Grant R826098-01-1

Iverson RL, Bittaker HF (1986) Seagrass distribution and abundance in the eastern Gulf of Mexico waters. Estuar Coast Shelf Sci 22:577-602

Jaramillo E, Bertran C, Bravo A (1992) Mussel biodeposition in an estuary in southern Chile. Mar Ecol Prog Ser 82: 85-94

Jordan JE, Valiela I (1982) A nitrogen budget of the ribbed mussel, Geukensia demissa, and its significance to nitrogen flow in a New England salt marsh. Limnol Oceanogr 27:75-90

Kautsky N, Evans S (1987) Role of biodeposition by Mytilus edulis in the circulation of matter and nutrients in a Baltic coastal ecosystem. Mar Ecol Prog Ser 38:201-212

Larkum AWD, West RJ (1990) Long-term changes of seagrasses in Botany Bay, Australia. Aquat Bot 37:55-70

McGlathery KJ (1992) Physiological controls on the distribution of the macroalga Spyridea-Hypnoides-patterns along a eutrophication gradient in Bermuda. Mar Ecol Prog Ser 87:173-182

Neckles HA, Wetzel RL, Orth RJ (1993) Relative effects of nutrient enrichment and grazing on epiphyte-macrophyte (Zostera marina L.) dynamics. Oecologia 93:285-295

Orth RJ, Moore KJ (1983) Chesapeake Bay: an unprecedented decline in submerged aquatic vegetation. Science 222:51-53

Orth RJ, van Montfrans J (1984) Epiphyte-seagrass relation- 
ships with an emphasis on the role of micrograzing: a review. Aquat Bot 18:43-69

Peterson BJ, Heck KL Jr (1999) The potential for suspension feeding bivalves to increase seagrass productivity. J Exp Mar Biol Ecol 240:37-52

Peterson BJ, Heck KL Jr (2001) Positive interactions between suspension feeding bivalves and seagrass - a faculative mutualism. Mar Ecol Prog Ser 213:143-155

Reusch TBH, Williams SL (1998) Variable responses of native eelgrass Zostera marina to a non-indigenous bivalve Musculista senhousia. Oecologia 113:428-442

Reusch TBH, Chapman ARO, Gröger JP (1994) Blue mussels Mytilus edulis do not interfere with eelgrass Zostera marina but fertilize shoot growth through biodeposition. Mar Ecol Prog Ser 108:265-282

Rudloe A (1985) Variation in the expression of lunar and tidal rhythms in the horseshoe crab, Limulus polyphemus. Bull Mar Sci 36:388-395

Short FT (1987) Effects of sediment nutrients on seagrasses:

Editorial responsibility: Otto Kinne (Editor),

Oldendorf/Luhe, Germany literature review and mesocosm experiment. Aquat Bot $27: 41-57$

Short FT, Neckles HA (1999) The effect of global climate change on seagrasses. Aquat Bot 63:169-196

Solorzano L, Sharp JH (1980) Determination of total dissolved phosphorus and particulate phosphorus in natural waters. Limnol Oceanogr 25:754-760

Stewart RA, Gorsline DS (1962) Recent sedimentary history of St. Joseph's Bay, Florida. Sedimentology 1:256-286

Valentine JF, Heck KL Jr (1993) Mussels in seagrass meadows: their influence on macroinvertebrate abundance and secondary production in the Northern Gulf of Mexico. Mar Ecol Prog Ser 96:63-74

Williams SL (1980) Experimental studies of Caribbean seagrass bed development. Ecol Monogr 60:449-469

Zieman JC (1974) Methods for the study of the growth and production of turtle grass, Thalassia testudinum. In: Cronin LE (ed) Estuarine research, Vol 1. Chemistry, biology and the estuarine system. Academic Press, p 541-562

Submitted: April 5, 2000; Accepted: September 29, 2000 Proofs received from author(s): July 23, 2001 